\title{
Rapid in vitro Regeneration and Clonal Propagation of the Fastest Growing Leguminous Tree Albizia falcataria (L.) Fosberg using Leaflet Explant
}

\author{
Nabarun Ghosh", Don W. Smith ${ }^{1}$ A. B. Das ${ }^{2}$ and A. Chatterjee ${ }^{3}$ \\ Department of Life, Earth and Environmental Sciences, West Texas AEM University, \\ Canyon, TX 79016, U.S.A.
}

Key words: Albizia falcataria, Leaf explant, Clonal propagation, Cytology

\begin{abstract}
Young leaflets were used as the explants for in vitro regeneration of Albizia falcataria (L.) Fosberg without callus intervention. The leaf explants produced in vitro adventitious shoot buds directly on culturing with MS supplemented with BA, IBA $(4.0 / 0.05 \mathrm{mg} / \mathrm{l})$ and $10 \%$ coconut milk (v/v). Addition of casein hydrolysate and coconut milk increased the production of shoot buds. The buds produced shoots and roots and showed 66\% survival in a field trial. This technique offers an effective way by which large number of genetically stable plants can be produced, maintained, multiplied and transported as disease free propagules or regenerants, safely and economically.
\end{abstract}

\section{Introduction}

Albizia falcataria (L.) Fosberg is evergreen and has a value in soil improvement and as shade on different crops. It is a fast growing tree that acquires about $3 \mathrm{~m}$ in height and $30 \mathrm{~cm}$ in girth in a year and offers enormous economic potential as a source of pulpwood (NAS 1979). For its fast growth rate and excellent biomass production the species has been selected for reforestation and social forestry programs, and as a shade tree on tea and coffee plantations (Dassanayake and Fosberg 1980, Sinha and Mallick 1993).

Studies on in vitro culture of different species of Albizia have been reported including A. julibrissin (Sankhla et al. 1993); A. lebbeck (Varghese and Kaur 1988, Tomar and Gupta 1988b); A. procera (Ghosh and Chatterjee 1992); A. richardiana (Tomar and Gupta 1988a). Sinha and Mallick (1993) first reported in vitro culture of A. falcataria. The effect of gamma radiation on in vitro culture of this species

${ }^{*}<$ nghosh@mail.wtamu.edu>. ${ }^{1}$ Department of Biological Sciences, University of North Texas, Denton, Texas 76203, U.S.A. <dsmith@unt.edu>. ${ }^{2}$ Department. of Agricultural Biotechnology, College of Agriculture, Orissa University of Agriculture \& Technology, Bhubaneswar-751003, India. $<$ a_b_das@hotmail.com>. ${ }^{3}$ CAS, Department of Botany, University of Calcutta, Calcutta-700.019, India. <prof_dr_ac@yahoo.co.in>. 
was also reported (Ghosh 1993, Ghosh et al. 1995). In those studies cotyledon explants were used to establish the cultures. Present communication reports on a successful in vitro regeneration of plantlets from shoot buds directly produced on leaflet explants, an accomplishment not previously reported for A. falcataria. The potential application of in vitro techniques for the genetic improvement and propagation of trees for the purpose of various economic uses has been described (Venkateswaran and Gandhi 1982). These techniques offer an effective way by which large numbers of genetically stable plants can be produced, maintained, multiplied and transported as disease free propagules or regenerants, safely and economically.

Callus cultures of forest trees, similar to that of herbaceous plants, display genetic instabilities: polyploidy, aneuploidy, etc. (Bonga 1977, D'Amato 1978). As it is evident that polyploidy and other chromosomal instabilities occur in tree callus cultures, it seems reasonable to expect that the apparently strong tendency away from polyploidy and homozygosity displayed in forest trees should ensure that regenerated plants will be normal diploids (Conger 1981).

In vitro regeneration of this tree species using young leaflets without callus intervention can open a new way for the important of tree species that could be useful for mass propagation and genetic improvement of this woody species.

\section{Materials and Methods}

Since the seed size often influences the germination rate (Foster and Janson 1985), only the uniform large, mature, dry and apparently healthy seeds of Albizia falcataria (L.) Fosberg were selected. The seeds were surface sterilized with 5\% Tween-20 for $20 \mathrm{~min}$ and washed with sterile distilled water. The seeds were germinated in hormone and vitamin free half strength of MS with $0.6 \%$ agar (w/v) (Fisher Scientific A360-500). After six weeks the expanded young leaflets were excised and inoculated aseptically on the modified MS with different concentrations and combinations: BA, Kn, IBA, NAA and growth supplements: coconut milk (CM) (v/v) and casein hydrolysate $(\mathrm{CH})(\mathrm{w} / \mathrm{v})($ Table 1$)$. Three per cent $(\mathrm{w} / \mathrm{v})$ sucrose was used in the medium and gelled with $0.5 \%(\mathrm{w} / \mathrm{v})$ agar powder. The $\mathrm{pH}$ of the media was adjusted to 5.8 before autoclaving at 1.05 $\mathrm{kg} / \mathrm{cm}^{2}$ and $121^{\circ} \mathrm{C}$ for 16 minutes. All aseptic manipulations were carried out under a laminar airflow hood. One hundred mg leaf explants were inoculated per culture tube keeping ten tubes as replica for each treatment (Table 1). After inoculation the culture tubes and vessels were maintained in the culture room at $25 \pm 1^{\circ} \mathrm{C}$ with $60 \%$ relative humidity under a $16 \mathrm{hr}$ photoperiod with 36 $\mu \mathrm{E} / \mathrm{cm}^{2} / \mathrm{sec}$ from cool white fluorescent light.

Of the different sets of culture, the leaf explants produced adventitious shoot buds directly on MS supplemented with $4.0 \mathrm{mg} / \mathrm{l} \mathrm{BA}, 0.05 \mathrm{mg} / \mathrm{l} \mathrm{IBA}$ and 10\% 
coconut milk (v/v) (Fig. 2A,B). There was an increase in number of shoot buds produced per $100 \mathrm{mg}$ of leaflet explant in the sets supplemented with $\mathrm{CH}$ and CM (Fig. 3).

Table 1. Response of leaf explants of A. falcataria in MS with BA, Kn, IBA and CM.

\begin{tabular}{|c|c|c|c|c|c|}
\hline $\begin{array}{c}\mathrm{BA} \\
(\mathrm{mg} / \mathrm{l})\end{array}$ & $\begin{array}{c}\mathrm{Kn} \\
(\mathrm{mg} / \mathrm{l})\end{array}$ & $\begin{array}{c}\mathrm{IBA} \\
(\mathrm{mg} / \mathrm{l})\end{array}$ & $\begin{array}{c}\mathrm{CM} \\
(\% \mathrm{v} / \mathrm{v})\end{array}$ & $\begin{array}{l}\text { Response of leaflet explants } \\
\text { (after } 21 \text { days) }\end{array}$ & $\begin{array}{c}\% \text { of explants } \\
\text { responded }\end{array}$ \\
\hline & 0.1 & 0.005 & 10 & No response & 0 \\
\hline & 0.2 & 0.01 & 10 & White friable callus, non-regenerative & $15-20$ \\
\hline & 0.5 & 0.02 & 10 & Light green friable callus & $15-20$ \\
\hline & 1.0 & 0.03 & 10 & Green compact callus & $25-30$ \\
\hline & 2.0 & 0.04 & 10 & $\begin{array}{l}\text { Green friable callus developed from } \\
\text { the cut end of the explant }\end{array}$ & $45-50$ \\
\hline & 4.0 & 0.05 & 10 & Hard compact green callus & $60-70$ \\
\hline & 6.0 & 0.1 & 10 & Yellowish green friable callus & $45-50$ \\
\hline 0.1 & & 0.005 & 10 & Leaflets enlarged & $20-25$ \\
\hline 0.2 & & 0.01 & 10 & $\begin{array}{l}\text { A few rows of cells emerged in the } \\
\text { margin of the leaflets }\end{array}$ & $20-25$ \\
\hline 0.5 & & 0.02 & 10 & $\begin{array}{l}\text { The leaflets became twisted, without } \\
\text { callusing }\end{array}$ & $15-20$ \\
\hline 1.0 & & 0.03 & 10 & $\begin{array}{l}\text { Light green callus emerged from the } \\
\text { cut end of the leaflets }\end{array}$ & $40-45$ \\
\hline 2.0 & & 0.04 & 10 & $\begin{array}{l}\text { Dark compact callus, } \\
\text { non-regenerative }\end{array}$ & $65-70$ \\
\hline 4.0 & & 0.05 & 10 & $\begin{array}{l}\text { Green globose shoot buds emerged } \\
\text { from the cut ends of the leaflets }\end{array}$ & $65-70$ \\
\hline 6.0 & & 0.1 & 10 & Green granular callus & $55-60$ \\
\hline
\end{tabular}

The regenerated microshoots (Fig. 2C) of $2-2.5 \mathrm{~cm}$ length were transferred to two sets of rooting media, one with and the other without agar (liquid) supplemented with IBA and NAA of different concentrations (Table 2). The rooted microshoots (2D) were transferred to vessels with filter paper bridges dipped in liquid Knop's medium (Evans and Nason 1953). They were held in the liquid medium for 10 - 12 days to have a balanced root/shoot development. The rooted plants $(2 \mathrm{~F})$ were transferred to pots for further growth in the green house (Fig. 2G).

For cytological observations root tips were excised from the regenerated plantlets, pretreated with a mixture of saturated solutions of para-dichlorobenzene : $0.0002 \mathrm{M}$ oxiquinolene $(1: 1)$ for $3 \mathrm{hr}$, fixed in Carnoy's fluid for $24 \mathrm{hr}$, hydrolyzed with $2 \mathrm{~N} \mathrm{HCl}$ at $60^{\circ} \mathrm{C}$ for $8 \mathrm{~min}$ and stained with $2 \%$ aceto-orcein for $45 \mathrm{~min}$. After squash preparation (Sharma and Sharma 1980), the well-scattered metaphase plates were observed under the high power and oil immersion lenses and photographs were taken using an Olympus BX40 microscope equipped with 
an Olympus DP-70 digital camera connected to the computer with Image Pro 6.0 software.

\section{Results and Discussion}

MS was used for in vitro regeneration of 25 species of legumes (Evans et al. 1983). $\mathrm{BA}$ and $\mathrm{Kn}$ were used of which BA showed better morphogenetic response (Table 1). Sometimes the addition of CM improved morphogenetic response. The leaf explants responded differently to different combinations and concentrations of growth factors added to MS (Table 1). Direct regeneration of shoot buds using MS supplemented with BA, IBA (4.0/0.05 mg/l) and CM 10\% (v/v) (Fig. 1) were obtained. The addition of $2-12 \mathrm{mg} / \mathrm{l} \mathrm{CH}$ with CM (50 - $100 \mathrm{mg} / \mathrm{l})$ increased the number of shoot buds per unit of leaflet explants (Fig. 1).

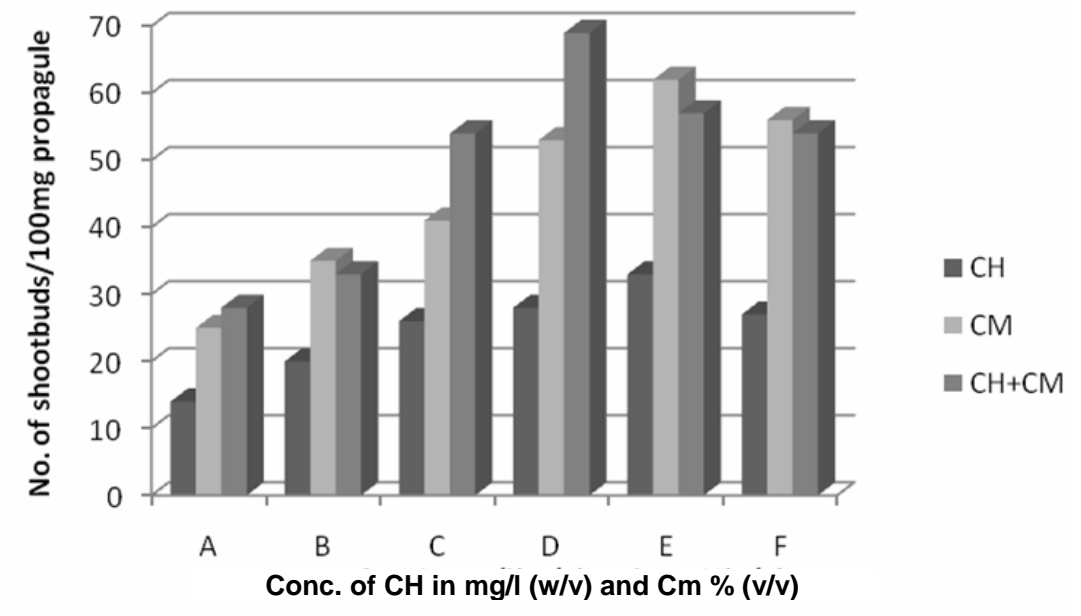

Set $\mathrm{A}=\mathrm{CH} 50 \mathrm{mg} / \mathrm{l}, \mathrm{CM} 2 \%(\mathrm{v} / \mathrm{v})$. Set B = CH $60 \mathrm{mg} / \mathrm{l}, \mathrm{CM} 4 \%(\mathrm{v} / \mathrm{v})$. Set C = CH $70 \mathrm{mg} / \mathrm{l}, \mathrm{CM} 6 \%$ (v/v). Set D = CH 80 mg/l, CM 8\% (v/v). Set E = CH 90 mg/l, CM 10\% (v/v). F = CH 100 mg/l, CM 12\% (v/v)

Fig.1. Effect of different concs. of $\mathrm{CM}$ and $\mathrm{CH}$ on shoot bud regeneration of A. falcataria.

Both the culture medium and the explants turned brown after two weeks of culture. Browning is generally resulted from the oxidation of phenolic compounds released from the cut ends of the explants by polyphenoloxidases (Mayer and Harel 1979), peroxidases (Vaughn and Duke 1984) or air (Robinson 1983). The oxidized products, quinones, are known to be highly reactive, inhibit enzyme activity and lead to the death of explants (Hu and Wang 1983). The inclusion of an antioxidant, polyvinylpyrrolidone (PVP) inhibited browning and subsequent death of the leaf explants. After several trials it was found that $0.5 \%$ PVP (w/v) prevented browning. PVP and polyvinylpolypyrrolidone (PVPP $\}$ were 

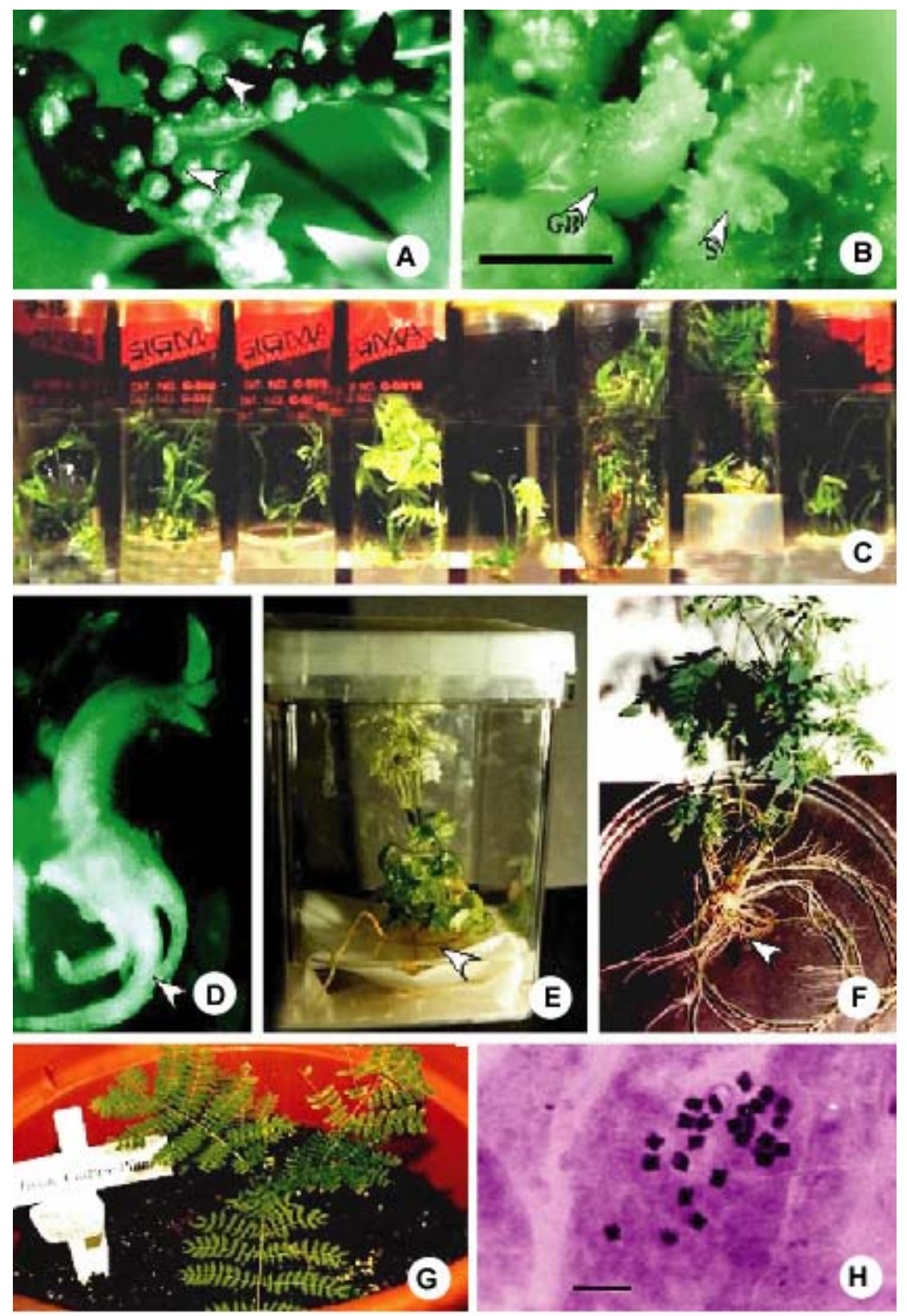

Fig. 2A-H: Steps of regeneration of Albizia falcataria from leaflet to the complete plant. A. Regeneration of shoot buds from the leaf explants. B. Shootlets emerged from the buds (GB points to the growing shoot bud and S pointing to the developing shoot). C. Further development of shootlets. D. Emergence of rootlets from the base on addition of IAA and NAA. E,F. Development of root system on filter paper bridge in liquid medium. G. Regenerated plant in the potting soil. H. Regenerated plants showed genetic stability with standard karyotype, $2 \mathrm{n}=26$ chromosomes. 
added to success in anther culture experiments, resulting in increased pollen embryogenesis probably due to adsorption of the phenol complexes or other inhibiting compounds (Tyagi et al. 1981).

The number of shoots produced per explant varied with the concentrations of $\mathrm{CM}$ and $\mathrm{CH}$ in the media (Fig. 1). Simultaneous use of both growth regulators showed a stimulatory effect that was on dependent concentration. The concentrations of $\mathrm{CM}$ and $\mathrm{CH}$ that produced the maximum number of shoot buds $(69 \pm$ Sd 3.6) per $100 \mathrm{mg}$ explants were CM $8 \%$ (v/v), CH $80 \mathrm{mg} / \mathrm{l}(\mathrm{w} / \mathrm{v})$. Increased concentration beyond this optimum of either $\mathrm{CM}$ or $\mathrm{CH}$ separately or in combination decreased production of shoot buds (Fig. 1). The steps of morphogenesis of the shoot buds were studied using an SZ-40 Stereo Microscope attached to a goose neck fiber optics light source. Fig. 2A, B and D are showing the stereo-micrographs of the emergence of shoot buds from the leaflet explants (A), shoot production (B) and root production from the shoot buds (D).

Addition of $\mathrm{CH}$ had a radio-protective effect on the callus tissue that sharply decreased the abnormality indices of the irradiated tissue compared to the culture that was not supplemented (Ghosh 1993).

The formation of organs from explants or callus cultured in vitro is a complex piece of plant morphogenesis that is usually influenced by hormonal constitution and growth factor concentration of the culture medium interacting factors complex enough to be very difficult to achieve in the laboratory (Christianson 1987). Independent of BAP concentration, elevated concentration of IBA yielded green shoot buds with white patches, which failed to produce shootlets. At higher concentrations of $\mathrm{CM}$ and $\mathrm{CH}$ the shoot buds were deformed in shape and failed to produce any shootlet. After a subculture it took two - three weeks for full emergence of the shootlets from shoot buds. Shoot buds that formed above the agar medium produced shootlets while those submerged in the agar medium did not produce any shoot until they were subcultured to the surface of the medium.

An exponential increase of the production of shoot buds occurred with repeated subculturing on fresh medium for a four - five months after which there was a sharp decline in regeneration efficiency. The number of shoot buds produced varied with the frequency of subculture (Fig. 3). After seven months of culture the regenerative potential declined by a significant level, similar to the findings of Franclet and Boulay(1989). It was noticed that long term culture of another leguminous tree Dalbergia sissoo Roxb. resulted in an accumulation of genetic errors (Ghosh et al. 1992, and Chatterjee 1998). Microshoots 3 - $4 \mathrm{~cm}$ long were transferred to two different sets of medium. One set was agarified half strength MS, the other was liquid half strength MS. Filter paper bridges were used in culture vessels with liquid half strength of MS, upon which shootlets 
were placed to achieve rooting. When NAA and IBA were added at concentrations higher than optimum $(2,0.25 \mathrm{mg} / \mathrm{l})$ it produced deformed or feeble roots that atrophied on subsequent subculture of the plantlets. Liquid half strength of MS modified with NAA ( $2 \mathrm{mg} / \mathrm{l})$ and IBA $(0.25 \mathrm{mg} / \mathrm{l})$ yielded the best result for rhizogenesis from the transferred microshoots (Table 2, Fig. 2F). The transfer from the liquid medium to the hardening solution was easier than the solid medium where there was a higher incidence of damage to the fragile root system. It was difficult to induce roots in the microshoots in the agarified media, a few sets of culture produced white friable callus at the base of the microshoots and failed to accomplish any rhizogenesis. Plantlets with a healthy and well formed root system were transferred to fresh liquid Knop's medium for hardening without the addition of any kind of growth factor. The vessels containing Knop's medium were covered with inverted beakers to maintain high humidity. These measures prevent sudden shock or environmental stress to the plantlets.

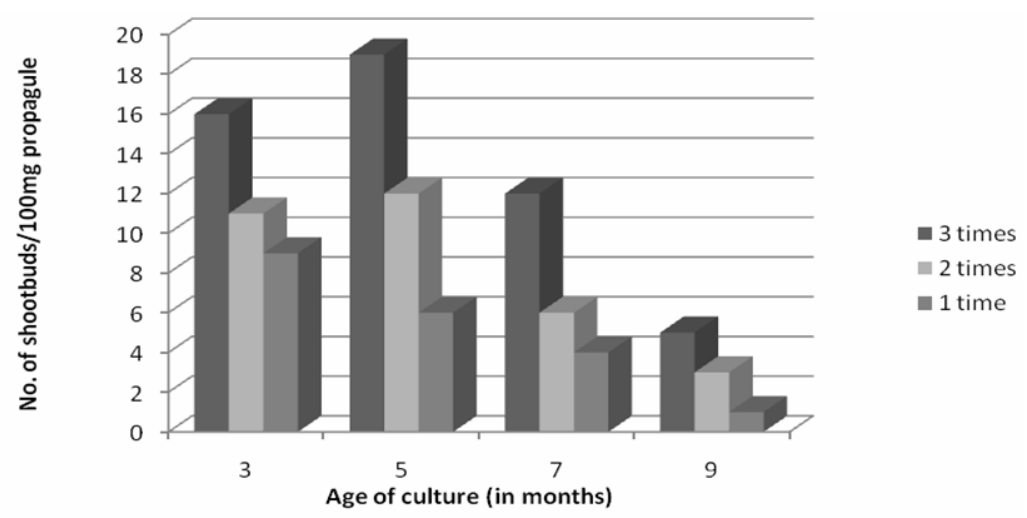

Fig. 3. Regeneration of shoot buds via in vitro culture of leaf explants of A. falcataria varied with the age and frequency of subculture.

Hardening is a critical step in in vitro propagation of any plant species. The standard procedure for hardening is to place the plantlets in sterile distilled water. In the present investigation it was found that a pre-exposure of the rooted plantlets in sterile Knop's medium (Salisbury and Ross 1985) for five - six days yielded a better survival rate in the greenhouse than with sterile distilled water.

In the next step the plantlets were transferred to sterile potting soil (Fig. 2G). The plants were about $20-22 \mathrm{~cm}$ long after 6 weeks when they were transferred to larger pots in the green house. Following the transfer from the culture room to pots, $55-60 \%$ plants survived. The survival rate was less (30 - 40\%) when plants were not hardened in Knop's medium. Sixty per cent plants survived in a field 
trial. Callus-mediated clones are usually genetically unstable. Plants regenerated from long term callus culture often lack morphological uniformity which is not desirable except in some special cytogenetic improvement programs when extensive screening for varied characters is needed. Cloning in vivo and in vitro of adult or mature woody plants is adversely affected by characteristics accompanying maturation such as reduced growth rate, reduced or total lack of rooting ability or sometimes the unpleasant phenomenon of plagiotropy (Thompson 1984, Hutchinson 1988). Since culture initiation also depends on the genotype of the plant and the developmental state of the tissue (Murashige 1974, Thomas et al. 1979, Green and Rhodes 1982, Harms et al. 1982) juvenile leaflets were selected as the initiating propagule for the establishment of in vitro culture.

Table 2. Liquid half strength of MS showing the rooting in the induction of microshoots.

\begin{tabular}{|c|c|c|c|c|}
\hline Set & $\begin{array}{l}\text { NAA } \\
(\mathrm{mg} / \mathrm{l})\end{array}$ & $\begin{array}{c}\text { IBA } \\
(\mathrm{mg} / \mathrm{l})\end{array}$ & $\begin{array}{l}\text { Response of microshoots } \\
\text { (after } 14 \text { days) }\end{array}$ & $\begin{array}{c}\% \text { of microshoots } \\
\text { responded }\end{array}$ \\
\hline 1. & 0.1 & 0.005 & No response & 00 \\
\hline 2. & 0.2 & 0.01 & No response & 00 \\
\hline 3. & 0.5 & 0.02 & $\begin{array}{l}\text { White friable callus from } \\
\text { the base of the microshoot }\end{array}$ & $18-20$ \\
\hline 4. & 1.0 & 0.20 & Rooting, roots are fragile & $35-40$ \\
\hline 5. & 2.0 & 0.25 & $\begin{array}{l}\text { Profuse rooting from the } \\
\text { microoshoots }\end{array}$ & $55-50$ \\
\hline 6. & 4.0 & 0.50 & A few roots developed & $25-30$ \\
\hline 7. & 6.0 & 0.1 & $\begin{array}{l}\text { Rooting, roots are } \\
\text { deformed and fragile }\end{array}$ & $10-12$ \\
\hline
\end{tabular}

In this investigation the leaflet explants showed a distinct morphogenetic response to particular concentrations of BA and IBA (Table 1). The morphogenetic response could be increased by the addition of two complex growth factors, $\mathrm{CM}$ and $\mathrm{CH}$. From the leaflet explants a large number of plantlets can be produced that can be increased exponentially by subsequent subcultures into fresh nutrient medium for a period of time. This avoids the anomalies associated with plants regenerated from callus, cell suspension and protoplast culture (Karp 1989, Larkin and Scowcroft 1981). The authors obtained cultured clones from leaf explants in a very short period and thus avoided the harmful interference of long-term callus culture. The regenerated plants were morphologically identical and were uniform in genetic constitution. Somatic metaphase plate from the root tips of plantlets regenerated in vitro showed a constant $2 \mathrm{n}=26$ chromosome number in a standard karyotype of Albizia falcataria (Fig. 2H). This corresponds to karyotypes from root tips of Albizia falcataria grown from seed (Ghosh 1993). The 
potential technology of clonal multiplication from leaflet explants without callus intervention will stimulate further research into in vitro culture of tree species, an area that needs much attention for clonal multiplication of tree species for proper utilization and conservation of their genetic resources.

\section{References}

Bonga JM (1977) Application of tissue culture in forestry. In: J. Reinert and YPS Bajaj (eds.), Plant Cell, Tissue and Organ Culture, Springer-Verlag, New York, p. 93.

Christianson ML (1987) Casual events in morphogenesis. In : CE Green (eds.), Plant Tissue and Cell Culture (Sixth International Congress on Plant tissue and Cell Culture, 1986 : University of Minnesota), Alan R. Liss Inc., NY, pp. 45-55.

Conger BV (1981) Cloning agricultural plants via in vitro techniques. CRC Press, Boca Raton, Florida. pp. 1-64.

D'Amato F (1978) Chromosome number variation in cultured cells and regenerated plants. In: TA Thorpe (eds.), Frontiers of Plant Tissue Culture 1978, the International Association of Plant Tissue Culture, Calgary, Canada, p. 287.

Dassanayake MD and Fosberg FR (1980) A revised handbook to the flora of Ceylon. Oxford and IBH publishing Co., New Delhi. pp. 1-20.

Evans HA and Nason A (1953) Knop's medium. In: Plant Physiology 28, pp. 233-254.

Evans DA, Sharp WR Ammirato PV and Yamada Y (1983) Handbook of Plant Cell Culture. MacMillan, New York, Vol. 1, pp. 24-67.

Foster SA and Janson CH (1985) The relationship between seed size and establishment conditions in tropical woody plants. Ecology 66: 773-780.

Franclet A and Boulay M (1989) In: JS Pereira and JJ Landsberg (eds.). Biomass production by fast growing trees Kluwer Acad. Pub. Dordrecht. pp. 267-274.

Ghosh N and Chatterjee A (1992) Cytological studies on the effect of gamma radiation on Albizia procera Benth. In: G.K. Manna and S.C. Roy (eds.). Perspectives in Cytology and Genetics 7: 1199-1209.

Ghosh N and Chatterjee A (1992) Cytological study on the effect of aging on callus cultures of Dalbergia sissoo Roxb. Plant Sciences in the Nineties, pp. 440-447.

Ghosh N (1993) Cytogenetical and tissue cultural investigations on some tree species, Ph.D. thesis in Botany, University of Calcutta, India. pp. 1-240.

Ghosh N Smith DW and Chatterjee A (1995) Cytological effects of gamma-radiation on in vitro culture of Albizia falcataria. G. K. Manna and S.C. Roy (eds.). Perspectives in Cytology and Genetics 8: 97-107.

Ghosh N, Chatterjee A, Sinha A and Smith DW (1998) Somaclonal variation in in vitro culture of Dalbergia sissoo Roxb. - a leguminous tree. 1998. GK Manna and SC Roy (eds.). Perspectives in Cytology and Genetics 9: 685-696.

Green C E and Rhodes CA (1982) Plant regeneration in tissue cultures of maize. In W.F. Sheridan (ed.) Maize for Biological Research. University of North Dakota Press, Grand forks, ND, USA. pp. 367-372.

Harms CT, Oertli JJ and Widholm JM (1982) Characterization of amino acid analogue resistant somatic hybrid cell lines of Daucus carota L. Z. Pflanzenphysiol 106: 239-49. 
Hu CY and Wang PJ (1983) In Evans DA, Sharp WR, Ammirato PV, Yamada Y (eds.). Handbook of Plant Cell Culture, Vol.1, Macmillan, New York, pp. 177-217.

Hutchinson KW (1988) In: JE Hallgren, (ed), Molecular genetics of forest trees (Proc. Frans. Kempe. Symp.) Umea, Sweden, pp. 101-114.

Karp A (1989) Can genetic stability be controlled in plant tissue cultures? IAPTC Newsletter 58: 2-11.

Larkin PJ and Scowcroft WR (1981) Somaclonal variation - a novel source of variability from cell cultures for plant improvement. Theor. Appl. Genet. 60: 197-214.

Mayer AM and E Harel (1979) Polyphenol oxidases in plants. Phytochemistry 18: 193-215.

Murashige T (1974) Manipulation of organ culture in plant tissue cultures. Botanical Bulletin of Academia Sinica 18: 1-24.

NAS (1979) Report on tropical Legumes: Resources for the future, National Academy of Sciences Pub. Washington, DC, pp. 173-177.

Robinson T (1983) The organic constituents of higher plants. 5th Ed. Cordus Press, North Amherst, Nass. pp. 1-5.

Salisbury FB and Ross CW (1985) Plant Physiology, 3rd Edition, Wadsworth, Belmont, California. p.197.

Sankhla D, Davis TD and Sankhla N (1993) Effect of gibberellin biosynthesis inhibitors on shoot regeneration from hypocotyl explants of Albizia julibrissin. Plant Cell Report 13: $115-118$.

Sharma AK and Sharma A (1980) Chromosome Technique: Theory and Practice. $3^{\text {rd }}$ Edition, Butterworths, London, pp. 68-470.

Sinha RK and Mallick R (1993) Regeneration and multiplication of shoot in Albizia falcataria. Plant Cell, Tissue and Organ Culture 32: 259-261.

Thomas E, King PJ and Potrykus I (1979) Improvement of crop plants via single cells in vitro - an assessment. Z. Pflanzenzuchtg. 82: 1-30.

Thompson DG (1984) in Seedling physiology and reforestation success (Durya ML and Brown GN ed.), M Nijhoff, Dordrecht. pp. 12-17.

Tomar UK and SC Gupta (1988a) Somatic embryogenesis and organogenesis in callus cultures of a tree legume, Albizia richardiana King. Plant Cell Rep. 7: 70-73.

Tomar UK and SC Gupta (1988b) In vitro plant regeneration of leguminous trees (Albizia sp.) Plant Cell Rep. 7: 385-388.

Tyagi AK, Rashid A and Maheshwari SC (1981) Promotive effect of Polyvinylpyrrolidone on pollen embryogenesis in Datura innoxia. Physiol. Plant 53: 405-406.

Varghese TM and Kaur A (1988) In vitro propagation of Albizia lebbeck Benth. Curr. Sci. 57: 1010-1012.

Vaughn KE and Duke SO (1984) Function of polyphenol oxidases in higher plants. Physiol. Plant 60: 106-112.

Venkateswaran S and Gandhi V (1982). Mass propagation and genetic improvement of forest trees for biomass production by tissue culture. Biomass. 2: 5-15. 